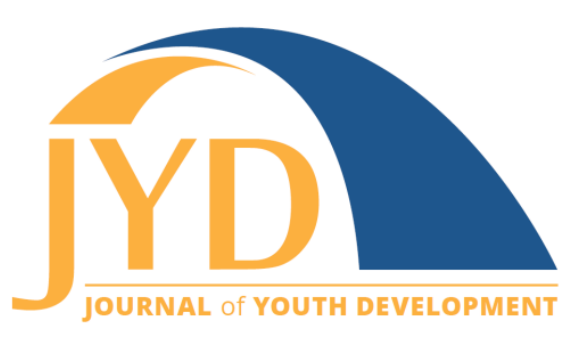

http://jyd. pitt. edu/ | Vol. 14 Issue 2 DOI 10.5195/jyd.2019.767 | ISSN 2325-4017 (online)

\title{
My Life So Far As a Young Immigrant
}

\section{Titus Kiragu Kariuki}

\begin{abstract}
Learning and adjusting to a new culture can often be an exciting and challenging experience. Young people experiencing new cultures hold a unique set of experiences that influence their transition into adulthood. The following essay highlights the experiences of a college freshman who recently immigrated from Kenya. The author tackles issues surrounding adjusting to new cultures and obstacles he has faced and highlights important life lessons that have helped his success.
\end{abstract}

Key words: optimistic, planned and organized, visionary, spontaneity, understanding, self-appreciation and motivation, love, friendship, family, God

\section{Introduction}

To begin with, I am an eighteen-year-old, living in Kent, Washington. As an immigrant from Kenya, I have been residing in the United States for less than a year now. I'm a permanent resident awaiting citizenship status in 2019, alongside my mum and two sisters. I currently study at Highline College, Des Moines, Washington. I'm currently undertaking an Associates of Science Degree in Computer Science and then pursue a four-year degree at a university of my choice. My younger sister is a senior at Kent Meridian High School, Kent, while my elder sister is currently pursuing a journalism degree at the University of Washington-Tacoma. My mum recently graduated from Highline College with a bachelor's degree in Human Services (with honors) and is currently self-employed as an instructor and founder of St. Bakhita Catholic Home for the Aged- Federal Way, Washington.

(cc) $\mathbf{E Y}$ New articles in this journal are licensed under a Creative Commons Attribution 4.0 License. This journal is published by the University Library System, University of Pittsburgh and is cosponsored by the University of Pittsburgh Press. The Journal of Youth Development is the official peer-reviewed publication of the National Association of Extension 4-H Agents and the National AfterSchool Association. 
My Life So Far As a Young Immigrant

In the past recent months, I would say that I've rather adapted myself in different ways pertaining to this foreign culture as well as observing different aspects of it, which I shall narrate in the given following questions.

\section{What is it like adjusting to life in a different culture?}

Adjusting to a different culture has been tricky since the ways of living are different as compared to those at home. For example, funny enough, every household has chicken or poultry in their freezer, which was rare to spot in Kenya (till it's even become boring now). I enjoyed beef back home, but all that changed on immigration, then beef became the new rare breed of chicken. Also, I've been observant of people sneezing while others "bless" them. Well, this wasn't that rare since back home in Kenya, a few people would use the "bless you" phrase whenever one sneezed. However, it was normal when the person sneezing would say "excuse me" after the first sneeze to be excused in case (s)he sneezed continuously. Since that changed, I might as well just preserve it in my vault of memories for the future.

\section{What obstackes have you overcome as you adjust to life in a new culture?}

A few obstacles I overcame in adjusting to a new culture include individualism and probably some financial difficulty too. In individualism, I may find that there are many Kenyans (and other communities) concentrated in one area, claiming the so-called, "unity," but what is meant is how each of them sticks up for themselves in their own capitalistic ideologies-every man for himself, and God for us all. This as I fear, might lead to some unwanted selfishness, not just to my own community, but rather all immigrant communities in the United States. I also suffer from financial constraints every now and then due to my increasing bills to pay, such as my insurance and car fuel, among other vital expenses, so I may have to resort to searching for a part-time job to keep my finances in check.

\section{Are you involved in any youth programs outside of school? If so, in what ways have these programs impacted your life?}

Programs outside school? Yes. I am currently enrolled at our local church youth: Holy Spirit Catholic Parish, in Kent, Washington. It is a group of dedicated youth volunteers who devote themselves to participating in useful local church and community projects. Some of these activities may include environmental cleaning, church service hosting and assisting the disabled 
My Life So Far As a Young Immigrant

of the society-the aged, homeless, needy, orphans and the physically impaired too. These activities have helped me grow spiritually, dutifully, responsibly and socially too, since I'm able to learn how to apply these aspects in different social settings regarding the activities being undertaken.

\section{Looking back, where and from whom did you learn the most important life lessons?}

That's a kind of a tricky question for me, since I've been learning lessons almost everywhere I go. But to start with, back in Africa, my father and grandparents used to invest in me by reminding me of the importance of family and good friends around me. They would give me stories of the present and the past, related to the same, and would also encourage me that wherever I go, I should always uphold and value the roots of my original homeland.

I also learnt the art of independence and self-sustenance from my mother, who still mentors me on the kind of decisions I make daily as an 18-year-old. That was the same way she taught my sisters to be, and hence were able to live by themselves since then. My mother also taught me decision-making, which is one of the most crucial life skills possessed by an individual. She says that the decisions I make are based on what I should feel is right for myself and not for others, and come to think of it, I agree with her on that.

\section{When things get tough, what keeps you going? Tell us how this inspires you to press on.}

This is a good question. As we all know, not all days are meant to be walks in the park, and such has been the same for me. Some days I may be lazy on myself, but on other days, whenever I wake up, I stare at the ceiling, comforting and encouraging myself that each day will be better than the previous one; today will be better than yesterday-if only I just make a little bit more effort towards achieving my daily goals, since after all, it's the little things that count first. Also, I also promise myself that I'll work so smart and hard enough, that I won't be in this same position next year (financially, mentally, socially, in school, moving homes and stuff like that.) I also remember that I have a family to help, a future to build, and even those I would like to bring into my life into the coming future, so that we may all traverse through it well. 


\section{Who or what has supported you? How has this been important for you?}

My main source of aid and assistance has been from my family and friends right here in the States. My mum has always been there for me to ensure that I get my required amenities, benefits and state rights too. My sisters have provided me with joy and fun that a family needs and I've also been making new friends who've helped me manage around different social scenarios such as school and social events. All these people around me have enabled me to create an everlasting bond of friendship, love and care, which I truly treasure eternally.

\section{How have your cultural values, faith, or spirituality shaped your life goals and experience(s)?}

How these factors have been shaping my life goals and experiences is simply clear for me; they renovate me as much as they innovate me. In that, they help me define myself, my relations to others and assist me in setting my own goals and priorities towards a given task. They've defined me who I am till now and I'm perfectly sure that I'll develop them to see what level is best for me and see if I can attain all that I can while I'm especially this young of age.

\section{Epilogue}

So from the above, I believe one can extract about my basic life in the United States so far. I've achieved a lot so far in my own essence, and I've made some mistakes too, which I can purposely admit. But eventually, I want to learn all there is to learn, while engaging and surviving in a foreign country. I am optimistic enough that someday I'll accomplish all my life goals and be contented and satisfied with all I have, as well as giving back and philanthropizing to all my friends, family and society in general., I see myself succeeding someday, and eventually being proud of the person I'll be glad I never gave up on.

So, help me God.

God's blessings, especially to all who read this.

Sincerely,

C.T.K 